\title{
Potential mechanism for the effects of dexamethasone on growth of human melanoma cells in vitro
}

\author{
Abdel-Moneim M. Osman ${ }^{1 \star}$, Omimah A. Nasseir ${ }^{2}$, Naglaa R. Ismail ${ }^{3}$ \\ ${ }^{1}$ College of Medicine, Pharmacology Department, King Abdulaziz University, Jeddah, Saudi Arabia; ${ }^{*}$ Corresponding Author: \\ moneimosman@hotmail.com \\ ${ }^{2}$ Science college of Girsl, King Abdulziz University, Jeddah, Saudi Arabia \\ ${ }^{3}$ Department of Zoology, Faculty of Science, Fayoum University, Fayoum, Egypt
}

Received 20 March 2010; revised 7 April 2010; accepted 10 April 2010.

\begin{abstract}
This study deals with the inhibitory effects of dexamethsone on the proliferation of a human melanoma cell line in vitro. A retarded cell proliferation was observed in M-5A cells with the presence of specific high affinity glucocorticoid steroid receptors. There was a correlation between the number of glucococrticoid binding sites and the reduction of cell proliferation in term of reduced plating efficiency. Arrest or accumulation of M-5A cells in $\mathbf{G 1}$ phase or both in $\mathbf{G 1}$ and G2 phase appeared to be involved in the growth inhibitory effect by dexamethsone. The magnitude and duration of cell cycle arrest up to 72 hours were dose dependent. There was a correlation between the duration of the disturbance of the cell cycle progression in M-5A cells after dexamethsone treatment and the inhibition of cell proliferation. Synthesis of receptor protein was not specifically stimulated or inhibited relative to the effect on cellular protein content in general. This may conclude that in the melanoma M-5A cell, death after glucocorticoid treatment is somehow related to the glucocorticoid receptor content and to the disturbance of cell cycle distribution.
\end{abstract}

Keywords: Melanoma Cells; Dexamethasone; Glucocorticoid Receptors

\section{INTRODUCTION}

Although malignant melanoma has not generally been regarded a hormonally responsive neoplasm, there is some evidence suggesting that melanoma may respond to the hormonal condition of the host. Pregnancy was reported to be associated with unfavorable prognosis in stage II disease [1]. However, adrenalectomy for melanoma metastatic to the adrenal gland provides good palliation of complete regression of distant metastatic melanoma after bilateral adrenalectomy, suggesting a possible role for adrenal hormones in modifying melanoma progression in certain patients [2]. A few reports have been published about the moderate sensitivity of human as well as animal melanoma to the action of glucocorticoid steroid hormones. Bregman et al. [3] found that dexamethsone at a concentration of $1 \mathrm{uM}$ inhibited the colony formation in a human melanoma cell strain (C8146c) by $60 \%$. Moreover, Ramirez et al. [4], showed $85 \%$ tumor rejection in mice challenged with $\mathrm{B} 16$ melanoma after administration of anti glucocorticoidinduced TNF receptor family related protein. Recently, Banciu et al. [5] reported that a glucocorticoid prednisolone phosphate encapsulated in long-circulating liposomes exerts antitumor activity through the inhibition of tumor angiogenesis. Therefore the aim of our study was directed to investigate to what extent glucocorticoid in term of dexamethasone affect human melanoma cells in vitro. Moreover, to study whether human melanoma cells contain glucocorticoid receptors and, if so, is there a relation between the sensitivity to glucocorticoid and the amount of receptors present.

\section{MATERIALS AND METHODS}

This study is partly conducted in the King Fahd Medical center, College of Medicine, King Abdulaziz University, Jeddah, Saudi Arabia and partly in Pharmacology Unit, National Cancer Institute, Cairo University.

\subsection{Cells and Cell Culture}

A human melanoma cell line $\mathrm{M}-5 \mathrm{~A}$ was received at unknown passage level from liquid nitrogen store National Cancer Institute, Cairo University. Its characteristics have been described [6]. 
Cells were grown in modified minimum essential Eagle's medium which penicillin (100 i.u./ml) and streptomycin $(100 \mathrm{ug} / \mathrm{ml})$ had been added to the medium contained $10 \%$ newborn calf serum inactivated by heating at $56^{\circ} \mathrm{C}$ for $30 \mathrm{~min}$. Cells were cultured at $37^{\circ} \mathrm{C}$ in humidified $5 \% \mathrm{CO}_{2}$ atmosphere.

\subsection{Evaluation of Drug Effect}

To study the effect of dexamethasone on cell proliferation, a colony forming assay has been used. Exponentially growing cells were trypsinized off the substratum and counted in a hemocytometer. Sufficient numbers of cells (500-5000) were plated in $25 \mathrm{~cm}^{2}$ Greiner flasks to yield between 15 and 300 colonies per flaks at the time of evaluation. The number of cells required for each experiment was determined in preliminary studies. After treatment for one hour, the incubation medium was replaced by fresh medium. After a time interval corresponding with nearly 5 to 7 doubling times of untreated cells, the number of colonies was counted and expressed as percent of the controls. To asses the cytotoxic action the per cent reduction in plating efficiency was calculated from the equation $(\mathrm{C}-\mathrm{T}) / \mathrm{C} \times 100$, where $\mathrm{C}$ and $\mathrm{T}$ are the final numbers of colonies in control and treated cultures, respectively.

\subsection{Glucocorticoid Receptor Assay}

Binding study for dexamethasone was carried out using a whole cell assay adapted from Rosner and Cristofalo [7] . Single cell suspensions were harvested from exponentially growing cultures, transfereed in triplicate to 60 mm Falcon dishes, $1 \times 10^{6}$ cells per dish, and incubated in growth medium. Twenty-four hours later, the medium was removed and cells were washed once with PBS at $22^{\circ} \mathrm{C}$. Fresh medium was added with $\left({ }^{3} \mathrm{H}\right)$ dexamethsone (40 Ci/mmole, Amersham International Ltd, England) or $\left({ }^{3} \mathrm{H}\right)$ dexamethsone in the presence of 1000 -fold excess concentration of unlabeled dexamethsone to measure total and nonspecific binding of dexamethasone to the cells, respectively. The cells were incubated for 60 or 90 min in a humidified $5 \% \mathrm{CO}_{2}$ atmosphere at $37^{\circ} \mathrm{C}$. Cells were then solubilized in $2 \mathrm{ml}$ of $0.5 \mathrm{M}$ sodium hydroxide at $50^{\circ} \mathrm{C}$ for one hour. After cooling the cells they were neutralized with $0.16 \mathrm{ml}$ of $6 \mathrm{~N}$ hydrochloric acid. And the cells transferred to scintillation vial and $15 \mathrm{ml}$ of Insta-gel scintillation liquid (Packard) was added. Radioactivity of the samples was determined in dpm in a Packard Model 3385 scintillation counter with an average efficiency for tritium of $34 \%$.

Specific binding of dexamethsone was calculated from the difference between the total binding of $\left({ }^{3} \mathrm{H}\right)$ dexamethsone at the saturating concentration of $4 \times 10^{-8}$ $\mathrm{M}$ dexamethasone and the nonspecific binding that occurred in the presence of excess unlabeled dexamethasone.
The molar amount of specifically bound $(3 \mathrm{H})$ dexamethsone was calculated from its specific radioactivity and the dpm/cell was measured. Conversion by Avogadro's number gave the number of specific binding sites per cells. Protein content was determined according to Lowry et al. [8].

\subsection{Flowcytometric Analysis}

Cell cycle analysis was performed using a flowcytomter ICP II (Phywe AG. Gottingen) equipped with a sheatflow cell essentially as described by Smets et al. [9] .Cells were stained by $2 \mathrm{ml}$ of solution which contained $2 \mathrm{mg}$ ethidium bromide, $0.8 \mathrm{mg}$ Hoechst stain 33258, $0.5 \mathrm{~g}$. bovine serum albumin and $2.4 \mathrm{~g}$ Tris $/ 100 \mathrm{ml}$. The percentage of cells with DNA per cell values corresponding with $\mathrm{G} 1, \mathrm{~S}$ or $\mathrm{G} 2 / \mathrm{M}$ phase were determined by planimetry of the histograms.

\section{RESULTS}

\subsection{Glucocorticoid Binding Sites}

Table 1 shows the relation between the duration of incubation with $\left({ }^{3} \mathrm{H}\right)$ dexamethsone and the specific and nonspecific binding by $10^{6}$ cells. Binding of the radioactive dexamethasone started rapidely as observed after 30 seconds of incubation. Maximum specific binding was achieved after 60-90 min. Prolongation of incubation to 120 min reduced the specific binding of glucocrticoid and increased the nonspecific binding. This decrease appeared not to be caused by the lower dexamethasone concentration during prolongation of the incubation (13 $\mathrm{nM}$ instead of $40 \mathrm{~nm}$ ) since $13 \mathrm{nM}$ must be considered nearly saturating according to the date in Figure 1. We have investigated the number of glucocorticoid binding site in melanoma M-5A cells after treatment with dexamethsone $2.5 \mathrm{uM}$ for one hour (Table 2). The number of dexamethasone binding site per cell was determined by the whole cell assay in control and treated culture. There was $31 \%$ increase in number of binding sites after 24 hours. The number of binding sites remained higher than in controls until the time that the treated cells resumed proliferation. The increase in the number of binding site/cells after dexamethsone treatment was dose dependant (Table 3). When measured 9 days after treatment with 2.5 or $12.5 \mathrm{uM}$ of dexamethsone a 2.8 -fold increase was observed at the higher concentration. Throughout these studies, it was noticed that the M-5A melanoma cells became larger during the growth delay induced by treatment with dexamethsone. Their total protein content was determined in order to see whether the increase in specific glucorticoid binding sites went parallel to a general increase in the amount of protein per cell. Table 4 showed a dose dependent increase in cellular protein content after dexamethsone treatment. 
Table.1. Time course of the specifically binding of $\left({ }^{3} \mathrm{H}\right)$ dexamethasone by M-5A melanoma cells.

\begin{tabular}{ccc}
\hline $\begin{array}{c}\text { Incubation } \\
\text { time } \\
(\mathrm{min})\end{array}$ & $\begin{array}{c}\text { Specific binding } \\
\text { of }\left({ }^{3} \mathrm{H}\right) \\
\text { dexamethasone } \\
\left(\mathrm{dpm} / 10^{6}\right) \times 10^{-3}\end{array}$ & $\begin{array}{c}\text { Nonspecific binding } \\
(\% \text { of total binding })\end{array}$ \\
\hline 0.5 & $1 \pm 0.2^{\mathrm{b}}$ & $93 \pm 0.6^{\mathrm{b}}$ \\
10 & $13 \pm 1$ & $79 \pm 1.5$ \\
40 & $17 \pm 1.6$ & $73 \pm 0.3$ \\
60 & $24 \pm 0.392$ & $64 \pm 0.8$ \\
90 & $23 \pm 1.5$ & $63 \pm 1.2$ \\
120 & $12 \pm 0.8$ & $77 \pm 1.0$ \\
\hline
\end{tabular}

${ }^{\mathrm{a}}$ Concentration $40 \mathrm{nM}$; ${ }^{\mathrm{b}}$ Presented are Mean \pm S.E.M. of triplicate flasks

Table 2. Specific glucocorticoid binding site in M-5A cells at various times after treatment with dexamethasone.

\begin{tabular}{cccc}
\hline \multirow{2}{*}{$\begin{array}{c}\text { Time after } \\
\text { Treatment } \\
(\mathrm{hr})\end{array}$} & \multicolumn{3}{c}{$\begin{array}{c}\text { Specific binding sites/cell } \\
\times 10^{-3}\end{array}$} \\
\cline { 2 - 4 } & Control & Treated & $\begin{array}{c}\text { Treated in } \\
\text { \% of control }\end{array}$ \\
\hline 24 & $132 \pm 2.5$ & $173 \pm 23$ & 131 \\
48 & $142 \pm 4.6$ & $189 \pm 27$ & 133 \\
72 & $108 \pm 1$ & $132 \pm 21$ & 123 \\
216 & $142 \pm 1$ & $189 \pm 17$ & 133 \\
\hline
\end{tabular}

ancubation for $60 \mathrm{~min}$ at $37^{\circ} \mathrm{C}$ with $40 \mathrm{nM}\left({ }^{3} \mathrm{H}\right)$ dexamethsone alone or in the presence of excess unlabeled steroid dexamethsone $2.5 \mathrm{uM}$ for one hour Presented are means \pm S.E.M.

Table 3. Effect of the dose of dexamethasone on the number of specific binding sites per M-5A melanoma cells, 9 days after treatment.

\begin{tabular}{cccc}
\hline \multirow{2}{*}{$\begin{array}{c}\text { Dexamethsone } \\
\text { concentration } \\
\text { (uM) }\end{array}$} & \multicolumn{3}{c}{$\begin{array}{c}\text { Specific binding sites per cells } \\
\times 10^{-3}\end{array}$} \\
\cline { 2 - 4 } & Control & Treated & $\begin{array}{c}\text { Treated in \% } \\
\text { of control }\end{array}$ \\
\hline 2.5 & $142 \pm 11$ & $189 \pm 17$ & 133 \\
12.5 & $131 \pm 0.3$ & $371 \pm 71$ & 283 \\
\hline
\end{tabular}

${ }^{1}$ Incubation for $60 \mathrm{~min}$ at $37^{\circ} \mathrm{C}$ with $40 \mathrm{nM}\left({ }^{3} \mathrm{H}\right)$ dexamethsone alone or in the presence of excess unlabeled steroid. Presented are mean \pm S.E.M.

From recalculation of the specifically bound dexamethsone in fmole/mg total cellular protein, it was observed that synthesis of receptor protein was not specifically stimulated or inhibited relative to the effect on cellular protein content in general.

\subsection{Cell Cycle Distribution after Dexamethsone Treatment}

Figure 2 shows the effect of dexamethasone treatment on the cell cycle phase distribution of M-5A melanoma cells at various time intervals. The pronounced effects were observed from 10 till 96 hours after treatment of M-5A cells for one hour with $2.5 \mathrm{uM}$ dexamethasone. At 10 hours after treatment a $90 \%$ reduction of S-phase cells was occurred (S-phase was nearly about $2 \%$ of total cell population). Gradual restoration of S-phase compartment started 24 hours after treatment but after 96 hours the relative number of $\mathrm{G} 2 / \mathrm{M}$ cell has not yet normalized.

\subsection{Relationship of Cell Cycle Perturbation to Cell Survival and Proliferation}

Twenty-four hours after cell incubation, dexamethsone was supplied at various concentrations from 0.25-12.5 $\mathrm{uM}$ for one hour (Table 5). After treatment the cells were washed, harvested and part of them was seeded to determine the rate of colony formation and absolute plating efficient (The ultimately surviving cell fraction). A dramatically lowering of the percentage of S-phase cells occurred at the lower concentration with decreasing the final plating efficiency. Increasing the dexamethasone concentration, the absolute plating efficiency attained plateau as did the perturbation in the cell cycle phases.

\section{DISCUSSION}

Malignant melanoma is a relatively uncommon disease comprising $1-3 \%$ of all cancers $[10,11]$. Melanoma has received considerable attention from both the clinical and investigational point of view due to marked tendency to disseminate and many patients die as result of distant metastases $[12,13]$. Glucocorticoid (triamcinolone) has shown an inhibitory effect on melanoma B16/F10 cell growth [14]. So this study was directed to gain better insight the role of glucocorticoid as modulators of cell growth as well as the presence and characteristics of glucocorticoid receptor in human melanoma M-5A cells. Our studies document the presence of specific, high affinity glucocortcoid binding site in M-5A human melanoma cells. The higher number of receptor sites in our melanoma cells are in good agreement with levels of the 65,000 to 96,000 sites per cell observed by Rosner and Cristofalo [7] in WI-38 human fibroblasts and with high expression of glucocorticoid receptors in human melanoma cells observed by Collinson et al. [2]. In our study M-5A cells were apparently, behaved differently from normal and leukemic lymphoblasts with regard to effect of dexamethsone treatment on the number of binding site/cells, since there was a dose-dependent increase in glucocoriticoid binding sites in M-5A cells after dexamethsone treatment. In contrast, shipman et al. $[15,16]$ found decrease in the glucocorticoid receptors after treatment with glucocorticoid in malignant cells from the 
peripheral blood of leukemic patients and in blood from normal volunteers, respectively. That could be due to an internal regulation of receptor levels in different responsive tumor.

Cell cycle analysis of M-5A cells after dexamethasone treatment showed depletion of S-phase 10 hours later with accumulation of the cells in G2/M phase (Figure 2). Moreover there was a good correlation between depletion of S-phase which, mean arrest in G1 phase and the cytotoxic activity of dexamethasone (Table 5). Early study by Smets et al. [9] has shown that prolonged glucocorticoid treatment of L1210 leukemic cells potentiated cytolysis by accumulation of the cells in the early G1 phase. So, the overall proposed that the antiproliferative effect of dexamethsone against growth of M-5A cells could be due to G1 arrest which enhanced the probability of transit to the G0 compartment in which dexamethasone mediated cytolysis would occur. Such effect may be medi-

Table 4. Specific glucocorticoid binding in relation to protein content of M-5A cells, 9 days after treatment with dexamethsone for one hour.

\begin{tabular}{ccccc}
\hline $\begin{array}{c}\text { Dexameth- } \\
\text { asone Con- } \\
\begin{array}{c}\text { centration } \\
(\mathrm{uM})\end{array}\end{array}$ & $\begin{array}{c}\text { Specific } \\
\text { binding } \\
\text { sites/cell }^{\mathrm{a}, \mathrm{b}} \\
\times 10^{-3}\end{array}$ & $\begin{array}{c}\text { Nonspe- } \\
\text { cific/total } \\
\text { specific } \\
\text { binding }^{\mathrm{a}, \mathrm{b}} \\
(\%)\end{array}$ & $\begin{array}{c}\text { Total } \\
\text { cellular } \\
\text { protein }^{\mathrm{a}, \mathrm{c}} \\
\left(\mathrm{ug} / 10^{6}\right. \\
\text { cells })\end{array}$ & $\begin{array}{c}\text { Specific } \\
\text { binding/mg } \\
\text { cellular } \\
\text { protein } \\
(\mathrm{fmol})\end{array}$ \\
\hline 0 & 131 & 59 & $362 \pm 55^{\mathrm{d}}$ & $601 \pm 92^{\mathrm{d}, \mathrm{e}}$ \\
2.5 & 172 & 60 & $554 \pm 16$ & $515 \pm 15^{\mathrm{e}}$ \\
12.5 & 300 & 61 & $1000 \pm 59$ & $489 \pm 29^{\mathrm{e}}$ \\
\hline
\end{tabular}

${ }^{a}$ Incubation for $60 \mathrm{~min}$ at $37^{\circ} \mathrm{C}$ with $40 \mathrm{nM}\left({ }^{3} \mathrm{H}\right)$ dexamethsone alone or in the presence of excess unlabeled steroid dexamethsone 2.5,12.5 $\mathrm{uM}$ for one hour; ${ }^{\mathrm{b}}$ Average number obtained from triplicate for total and nonspecific binding, respectively; ${ }^{\mathrm{c}}$ Mean data from two sister flasks; ${ }^{\mathrm{d}}$ resented are mean \pm S.E.M.; ${ }^{\mathrm{e}}$ Not significantly different.

Table 5. Relationship between cell cycle phase distribution proliferation rate and plating efficiency of M-5A cells after treatment with various concentration of dexamethasone.

\begin{tabular}{|c|c|c|c|c|c|}
\hline \multirow{2}{*}{$\begin{array}{l}\text { Dose }^{a} \\
(\mathrm{uM})\end{array}$} & \multicolumn{3}{|c|}{$\begin{array}{c}\text { Cell cycle distribution } 24^{b} \\
\text { hours after treatment }\end{array}$} & \multirow{2}{*}{$\begin{array}{c}\text { No. of visi- } \\
\text { ble colonies } \\
8 \text { days after } \\
\text { treatment } \\
\text { (\% of con- } \\
\text { trol) }\end{array}$} & \multirow{2}{*}{$\begin{array}{c}\text { Final } \\
\text { plating } \\
\text { efficiency } \\
\text { (\% of } \\
\text { control) }\end{array}$} \\
\hline & G1\% & $\mathrm{S} \%$ & $\mathrm{G} 2+\mathrm{N}$ & & \\
\hline 0 & $63 \pm 4$ & $21 \pm 4$ & $16 \pm 6$ & $100 \pm 7$ & 10 \\
\hline 0.25 & $66 \pm 5$ & 10 & 24 & 7 & 9 \\
\hline 1.25 & $63 \pm 3$ & $7 \pm 1$ & $30 \pm 4$ & $51 \pm 2$ & $78 \pm 4$ \\
\hline 6.25 & $66 \pm 2$ & $7 \pm 3$ & $27 \pm 1$ & $35 \pm 4$ & 60 \\
\hline 12.5 & $62 \pm 11$ & $7 \pm 3$ & $31 \pm 8$ & $20 \pm 1$ & $56 \pm 2$ \\
\hline
\end{tabular}

${ }^{a}$ Dexamethsone was supplied for one hour and 24 hours later the cells were collected as described in the materials and methods; ${ }^{b}$ Presented are mean \pm S.E.M. of two separate experiment, 3 flasks for each experiment.

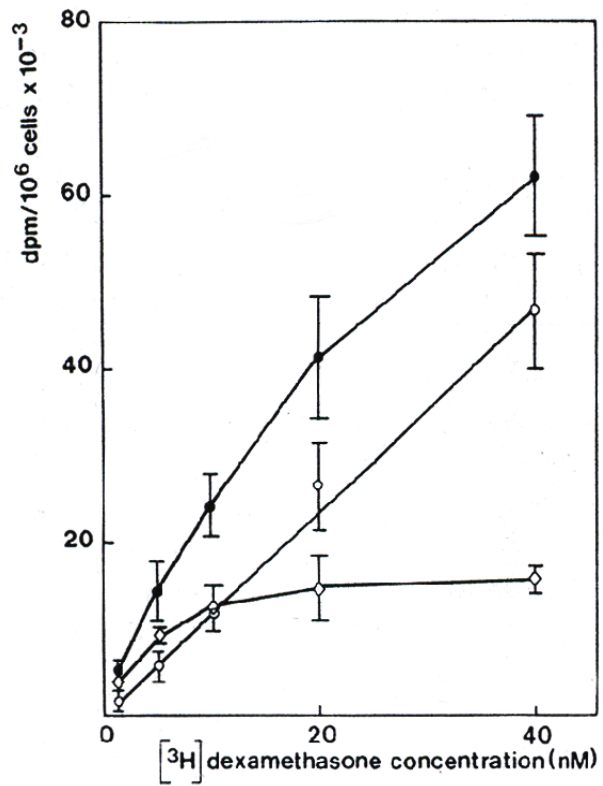

Figure 1. Binding of $\left({ }^{3} \mathrm{H}\right)$ dexamethasone by M-5A melanoma cells $\left(\mathrm{dpm} / 10^{6}\right.$ cells) at different drug concentration. Average data ( $\mathrm{M} \pm$ S.E.M.) from four experiment.Incubations were for 60 mininutes at $37^{\circ} \mathrm{C}$. $\cdot$ total binding, ${ }^{\circ}$ nonspecific binding, $\diamond$ specific binding.

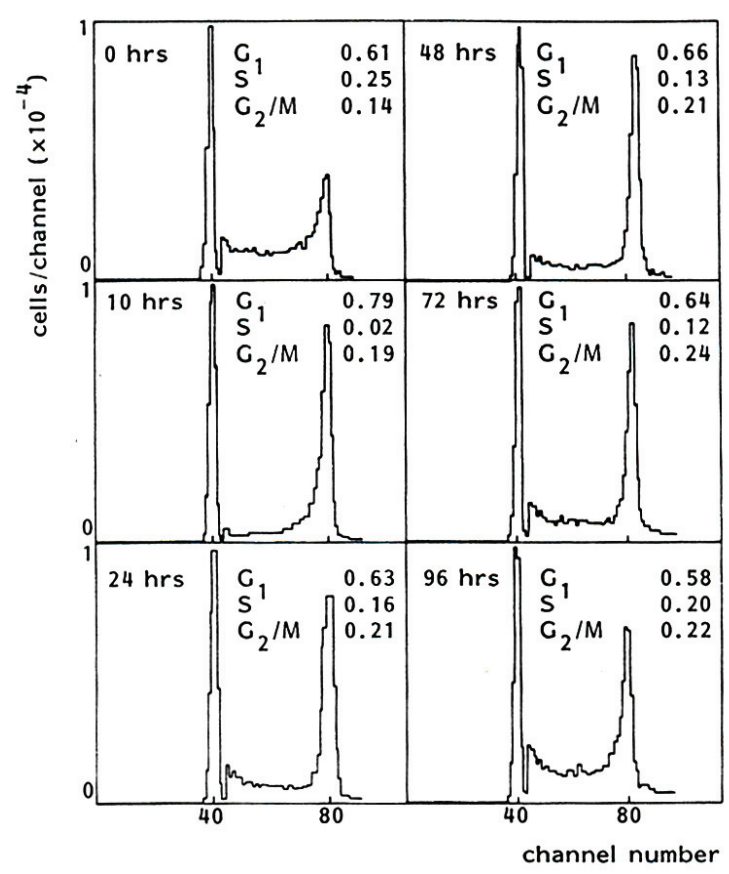

Figure 2. Effect of dexamethsone treatment (2.5 uM for 60 $\mathrm{min}$ ) on cell cycle phase distribution of M-5A cells at the indicated hours post-treatment. X-axis, channel number (relative DNA/cell); Y-axis, cell/channel $\left(\times 10^{-4}\right)$. Channels 45-120 (S and $\mathrm{G} 2 / \mathrm{M}$ ) amplified 4-fold. Relative compositions are given in the figure. 
ated by glucocorticoid receptors since Ramirez et al. [4] have reported activation of TNF receptor family related gene which overcomes tolerance/ignorance to melanoma differentiation antigen and enhanced antitumor immunity. In addition, Dobos [17] reported that 2-methoxyestradiol effectively inhibited melanoma cell proliferation by inducing apoptosis and an arrest in the G2/M phase. The mechanism of action involved microtubules, mitochondrial damage and caspase activation as well.

In SCID mice, 2-methoxyestradiol was effective in reducing primary tumor weight and the number of liver colonies after intrasplenic injection of human melanoma cells, and causing significantly higher rate of apoptotic cells in colonies.

Although a study from a single established human melanoma cell line, no general conclusion can be drawn neither with respect to the exact basis for the observed cytotoxic activity in the M-5A cell line nor to clinical implications, the results as presented might stimulate the development of new approaches in the systemic chemotherapy for malignant melanoma.

\section{REFERENCES}

[1] Shiu, M.H., Schottenfeld, D., Maclean, B. and Fortner, J.G. (1976) Adverse effect of pregnancy on melanoma. A reappraisal. Cancer, 37(1), 181-187.

[2] Collinson, F.J., Lam, T.K., Bruijn, W.M., De Wilt, J.H., Lamont, M., Thompson, J.K. and Kefford, R.F. (2008) Long-term survival and occasional regression of distat melanoma metastases after adrenal metastectomy. Annals Surgical Oncology, 15(6), 1741-1749.

[3] Bregman, M.D., Peters, E., Sander, D. and Meyskens, F.L. Jr. (1983) Dexamethsone, prostaglandin A and retinoic acid modulation of murine and human melanoma cells grown in soft agar. Journal of the National Cancer Institute, 71(5), 927-932.

[4] Ramirez, M.T, Chow, A., Hirschhorn, C.D., Terwey, T.H., Hochma, A.A., Lu, S., Miles, R.C., Sakaguchi, S., Houghton, A.N. and Van den Brink, M.R. (2006) Glucocorticopid-induced TNF receptor family related gene activation overcomes tolerance/ignorance to melanoma differentiation antigens and enhances antitumor immunity. Journal of Immunology, 176(11), 6434-6442.
[5] Banciu, M., Metselaar, J.M., Schiffelers, R.M., Storm, G. (2008) Antitumor activity of liposomal prednisolone phosphate depends on the presence of functional tumor-associated macrophages in tumor tissue. Neoplasia, 10(2), 108-117.

[6] Liao, S.K., Dent, P.B. and McCulloch, P.B. (1971) Characterizatiof of human malignant melanoma cell lines. I. morphology and growth characteristics in culture. Journal of the National Cancer Institute, 54(5), 1037-1044.

[7] Rosner, B.A. and Cristofalo, V.J. (1981) Changes in specific dexamethsone binding during aging in WI-38 cells. Endocrinology, 108(5), 1965-1971.

[8] Lowry, O.H., Rosenbrough, N.J., Farr, A.L. and Randall, R.J. (1951) Protein measurement with the folin phenol reagent. Journal of Biological Chemistry, 193(1), 265275

[9] Smets, L.A., Bout, B., Brouwer, M. and Tulp, A. (1983) Cytotoxic effect of dexamethsone restricted to noncycling, early G1 phase cells of L1210 leukemia. Journal of Cellular Physiology, 116(3), 397-403.

[10] McCarthy, W.H., Black, A.L. and Milton, G.W. (1980) Melanoma in New South Wales: An epidemiologic survey 1970-1976. Cancer, 46(2), 427-432.

[11] Nathanson, L. (1983) Epidemiologic and etiologic considerations in malignant melanoma. In: Costanzi, J.J., Ed., Malignant Melanoma 1, Cancer Treatment and Research, 9, 1-27.

[12] Comis, R.L. (1976) DTIC (NSC-45388) in malignant melanoma: A perspective. Cancer Treatment Reports, 60(2), 165-176.

[13] Costanzi, J.J. (1983) The chemotherapy of malignant melanoma. In: Costanzi, J.J., Ed., Malignant melanoma 1. Cancer Treatment and Research, 9, 259-274.

[14] Ristic-Fira, A., Vujcic, M., Krstic-Demonacos, M. and Kanazir, D. (1999) Identification and characterization of glucocorticoid receptors in B16 mouse melanoma cells. Endocrine Regulations, 33(3), 109-115.

[15] Shipman, G.F., Bloomfield, C.D., Smith, K.A., Peterson, B.A. and Munck, A. (1981). The effect of glucocorticoid therapy on glucocorticoid receptors in leukemia and lymphoma. Blood, 58(6), 1198-1202.

[16] Shipman, G.F., Bloomfield, C.D., Gajl-Peczalaska, K.L., Munck, A.U. and Smith, K.A. (1983) Glucocrticoid and lymphocytes.III. Effect of glucocoorticoid administration on lymphocyte glucocorticoid receptors. Blood, 61(6), 1086-1090.

[17] Dobos, J. (2009) Endocrine factors influencing melanoma progression. Magyar Onkologia Journal, 53(1), 47-50. 